\title{
Evaluation of Sesuvium portulacastrum for the Phytodesalination of Soils Irrigated over a Long-Term Period with Paper Mill Effluent under Non-leaching Conditions
}

\author{
B.R. Iniyalakshimi ${ }^{1}$, S. Avudainayagam ${ }^{2}$, R. Shanmugasundaram ${ }^{1}$, \\ S. Paul Sebastian ${ }^{2}$ and P. Thangavel ${ }^{2}$ \\ ${ }^{1}$ Department of Soil Science and Agricultural Chemistry, ${ }^{2}$ Department of Environmental \\ Sciences, Tamil Nadu Agricultural University, Coimbatore, India \\ *Corresponding author
}

\section{A B S T R A C T}

\begin{tabular}{l} 
K e y w o r d s \\
$\begin{array}{l}\text { Treated paper mill } \\
\text { effluent, Saline- } \\
\text { sodic soil, } S \text {. } \\
\text { portulacastrum, } \\
\text { Osmolyte } \\
\text { accumulation }\end{array}$ \\
$\begin{array}{l}\text { Article Info } \\
\text { Accepted: } \\
10 \text { November } 2019 \\
\text { Available Online: } \\
10 \text { December } 2019\end{array}$ \\
\hline
\end{tabular}

Paper and pulp mills discharge large volumes of wastewater into the environment. Crop productivity can be improved by using this wastewater, which is rich in salts and nutrients, as an irrigation source improves crop productivity by supplying enormous amount of nutrients. But for a long termit leads to development of soil salinity and sodicity and also calcareousness. Since leaching of salt affected soils with good quality water is impossible because of its non-availability in the study area, an attempt was made in the present study with the technique of phytodesalinisation using halophytes for remediation. Sesuvium portulacastrum, a facultative halophyte is widely studied for its phyto-desalinisation capacity of salt affected soils. Hence, present work was carried out to evaluate the $S$. portulacastrum for desalinization of saline-sodic soils of long term treated paper mill effluent irrigating soils. The halophyte found to have maximum sodium absorption and reduced the soil salinity considerably with 56.8 per cent reduction in ECe of the soil. A pot experiment was conducted in the long term treated effluent irrigating soils using good quality irrigation water and treated effluent as a source of irrigation. The cultivation of $S$. portulacastrum under treated effluent irrigating soils showed significant absorption of sodium ions and their accumulation in the shoot portion with the leaves having the highest $\mathrm{Na}$ and $\mathrm{Cl}$ content. Physiological, anatomical and biochemical studies showed the tolerance potential of $S$. portulacastrum to salt stress by accumulating osmolytes. Thus $S$. portulacastrum may possibly an ideal candidate for reclamation of salinity induced by treated paper mill effluent irrigation.

\section{Introduction}

The paper and pulp industry is one of the largest industries in the world and consumes large quantities of water. Nearly $75 \%-95 \%$ of the fresh water used in a paper and pulp mill is discharged as wastewater into the environment. The paper and pulp industry is categorised as one of the 17 most polluting industries in India (Sharma et al., 2014). 
According to the technology adopted, 72-225 $\mathrm{m}^{3}$ wastewater is released per ton of paper produced (Tripathi et al., 2014). This wastewater is used as an irrigation source because it contains supplementary nutrients (Rezende et al., 2010). Generally, the wastewater from a pulp and paper mill is alkaline, with a $\mathrm{pH}$ ranging from 7.2 to 9.4.It has a high electrical conductivity. The wastewater contains a high concentration of sodium chloride and appreciable concentration of carbonate and bicarbonate. It exhibits a tendency to precipitate calcium in the soil as $\mathrm{CaCO}_{3}$. Thus, the waste water increases the proportion of sodium to calcium and magnesium and the sodium adsorption ratio of the soil solution (Sharma et al., 2014), which leads to the development of salinity, sodicity, and calcareousness.

Saline-sodic soils can be reclaimed to an extent by removing the saline soil and replacing monovalent sodium ions with divalent cations, such as calcium, to improve the soil quality and crop productivity. A conventional technique for reclaiming salinesodic soils involves leaching the soil with good-quality water to remove excess saline salts (Abrol et al., 1988) and applying gypsum as an amendment. Phytoremediation is an alternate technique that involves using plants to remove, accumulate, transform, or diminish contaminants in soil (Kömives and Gullner, 2000). Phytoextraction is an important method for the phytoremediation of salt-affected soils. Phytoextraction involves using plants to store salt in shoots. The salt can then be removed from the soil by harvesting the plants/above ground biomass (Laboratory, 2000). Although a high salt concentration aids the growth of halophytes, where as it is toxic to glycophytes (Messedi et al., 2004), by disturbing their metabolic functions (Lokhande et al., 2010). To overcome the surplus salt conditions, halophytes possess several adaptation mechanisms, such as exclusion, compartmentalisation of toxic ions
(Hasanuzzaman et al., 2014), or utilization of osmoprotectants (Coll et al., 1998). Halophytes present in chloride-rich environments possess succulent morphology with chloride ions accumulated in the cytoplasm. Halophytes lack succulent morphology when there exists a shortage of chloride ions in them. These adaptations allow halophytes to obtain the water essential for their survival from the soil.

Sesuvium portulacastrum $L$. is a multipurpose facultative halophyte that belongs to the Aizoaceae family. S. portulacastrum L. may be an ideal candidate for the phytoremediation of salt-affected soil because it forms even in poor nutrient conditions and can also be used as forage for cattle (Lokhande and Suprasanna, 2012); (Rabhi et al., 2010). S. portulacastrum can accumulate excess $\mathrm{Na}^{+}$in the vacuoles by increasing the size of vacuoles and maintaining cytosolic metabolism (Lokhande and Suprasanna, 2012). Moreover, the accumulation of proline in large amounts as an osmoprotectantis a major salt adaptation mechanism (Moseki and Buru, 2010).Several studies have proved the desalination efficiency of $S$. portulacastrum in salt-affected soils under nonleaching conditions (Rabhi et al., 2010; Ravindran et al., 2007). Few studies have also proved the desalination efficiency of S. portulacastrum in industrial-waste-wateraffected soils (Sundararaj et al., 2014; Ramesh Kannan et al., 2009).

The aim of this study was to identify a suitable method for remediating salt-affected soils (saline-sodic soils) irrigated for a long-term period with paper mill effluent. Leaching salts with good-quality water is impossible in the study area. Hence, phytodesalination was performed with $S$. portulacastrum. The salt removal mechanism and growth response of $S$. portulacastrum were investigated by determining the physiological and biochemical parameters of the halophyte. 


\section{Materials and Methods}

\section{Soil and plant material}

The soil samples required for the study were collected from the soil areas irrigated with paper and pulp mill effluent for a long-term period. The samples were collected from locations at latitudes between $11.01^{\circ} \mathrm{Nand}$ $11.50^{\circ} \mathrm{Nand}$ longitudes between $77.987^{\circ} \mathrm{E}$ and $78.012^{\circ}$ E.Pichavaram is the second largest mangrove forest in the world, and the salty marsh area of Pichavaram is a habitat for many types of obligate and facultative halophytes.

Hyper-salt-accumulating $S$. portulacastrum samples were collected for remediating the salt-contaminated soils from Pichavaram forest. The collected hyper-salt-accumulating plant was identified and confirmed as $S$. portulacastrum through the Botanical Survey of India, Coimbatore. The collected plants were multiplied under optimum conditions. $S$. portulacastrum cuttings of three to four leaves without roots (approximately $5-7 \mathrm{~cm}$ in size) were used as planting material for phytodesalination.

\section{Treatments}

To study the phytodesalination efficiency of $S$. portulacastrum for soils irrigated with treated paper mill effluent, treatments were performed with and without the halophyte. Moreover, the treated paper and pulp mill effluent was used as an irrigation source with 36 replications. An adequate amount of soil was shade-dried. Large debris were removed. Subsequently, 10 $\mathrm{kg}$ soil was transferred to nonperforated pots to prevent the leaching of salts from the soil. Four $S$. portulacastrum cuttings were planted in each pot (Fig. 1-3).

A second experiment was performed to study the changes in the salinisation after irrigation with treated effluent $\left(\mathrm{T}_{1}\right)$ and good-quality water $\left(\mathrm{T}_{2}\right)$. The effect of salinisation on the physiological and biochemical parameters of $S$. portulacastrum in saline-sodic soils was also determined. An adequate amount of soil was shade-dried, large debris were removed, and subsequently $10 \mathrm{~kg}$ soil was transferred to nonperforated pots to prevent the leaching of salts from the soil. F our $S$. portulacastrum cuttings were planted in each pot.

In both the experiments, irrigation was performed according to the field capacity of the soil (22.5\%), which was estimated using a pressure plate apparatus (Obi, 1974). The initial weight of the pots after irrigation source addition based on FC was noted. The pots were weighed each time before irrigation, and a reduction in the weight was considered as a requirement for maintaining the field capacity of the soil. The physiological and biochemical measurements were performed 30 days after planting. Studies have indicated that after 90 days, a decrement occurs in the biomass productivity and salt uptake due to the ageing, disintegration, or nonavailability of nutrients (Sundararaj et al., 2014). Hence, $S$. portulacastrum was grown for 90 days and then harvested.

\section{Soil analysis}

The soil samples obtained before and after the experiment were shade-dried and processed using a 2-mm sieve before the analysis. The soil texture was identified according to the protocol of ISSS (Science, 1929). The $\mathrm{pH}$ and ECe were estimated in saturation paste extracts. The soil organic carbon was estimated using the wet digestion method (Walkley and Black, 1934).

The available nitrogen and phosphorus were estimated using the methods of (Subbiah and Asija, 1956) and (Olsen et al., 1954), respectively. The sodium and potassium 
content was estimated using flame photometry (Stanford and English, 1949), whereas the calcium and magnesium content was estimated through the Versenate method (Jackson, 1973).

\section{Plant analysis}

The leaves, stem, and root of the plant samples were separated from each other and then weighed, oven-dried, and ground to determine the plant ion composition.

Completely expanded fresh leaf samples were harvested between 8.00 and 9.00 am (carried using an ice box) to obtain the biochemical and physiological parameters, such as the free proline content(Bates et al., 1973).

The total soluble sugars was estimated using the anthrone method (Watanabe et al., 2000). The electrolyte leakage rate (ELR) and chlorophyll content were evaluated through the methods of Lutts (Lutts et al., 1995) and Lichtenthaler (Lichtenthaler, 1987), respectively. The lipid peroxidation in terms of the malondialdehyde (Majumdar et al.,) content was also determined (Heath and Packer, 1968).

$\mathrm{Na}^{+}$and $\mathrm{K}^{+}$were assayed through flame emission spectrophotometry (Labtronics, LT671) after triacid extraction $\left(\mathrm{HNO}_{3}: \mathrm{H}_{2} \mathrm{SO}_{4}: \mathrm{HClO}_{4}-9: 2: 1\right)$ of the finely grounded dry matter of the leaf, stem, and root samples. $\mathrm{Ca}^{2+}$ and $\mathrm{Mg}^{2+}$ were analysed through the Versenate method by using the acid extract.

\section{Statistical analysis}

The statistical parameters, namely the mean, standard devaiton (Havlin et al., 2005), and standard error (SE) for the physicochemical parameters were determined using SPSS Version 16.
The mean and SDs were calculated to determine the chemical parameters that deviated from the standards.

\section{Results and Discussion}

\section{Characteristics of the soil and irrigation water}

The soil used in the experiment belongs to the Vannapatti series, is a member of the Typic Ustorthents category, and is classified as red loamy sand (sand: $71 \%$, silt: $20 \%$, and clay: 9\%).The soil is highly saline-sodic and has a $\mathrm{pH}$ of 8.17 , ECe of $4.57 \mathrm{dSm}^{-1}$, and exchangeable sodium percentage (Zafrilla $e t$ al.,) of $33.93 \%$. The soil has a medium organic carbon content $(0.56 \%)$, low available nitrogen content, and high available phosphorus and potassium content.

The treated paper mill effluent had a high salt (especially sodium and chloride) and bicarbonate content. The characteristics of the effluent were within the requirements of the Indian Central Pollution Control Board (CPCB) standards of industrial wastewater for inland surface irrigation (Table 2).

\section{Phytodesalination of effluent-irrigated soil}

The continuous addition of treated effluent in the soil as an irrigation source considerably increased the salinity and sodicity (Tables 1 and 3), which indicates that the salt stress increased during the growth period of the plant.

The initial ECe (EC from the saturation paste extract) was $4.57 \mathrm{dSm}^{-1}$. However, the ECe significantly reduced to $3.01 \mathrm{dSm}^{-1}$ at $90 \mathrm{DAP}$ for the $S$. portulacastrum cuttings. The ECe increased to $6.97 \mathrm{dSm}^{-1}$ on the addition of treated effluent (without halophyte; Table 3). A 56.8\% reduction in the ECe of the soil occurred due to phytodesalination with 
Sesuvium, whereas a $52.5 \%$ increase in the ECe of the soil was observed in the treatment without halophyte. Thus, the phytodesalination capacity of $S$. portulacastrum under nonleaching conditions was verified (Rabhi et al., 2010).

On phytodesalination, a $37 \%$ and $33 \%$ reduction was observed in the number of exchangeable sodium and chloride ions, respectively. On treatment without the halophyte, the number of exchangeable sodium and chloride ions increased by $37.5 \%$ and $40.6 \%$, respectively. A $22 \%$ reduction was observed in the ESP of the phytodesalinsed soil. An increase of $4.7 \%$ was noted in the ESP of the soil treated without the halophyte. Thus, Sesuvium accumulated a larger amount of sodium ions than other cations, which led to a significant reduction in the ESP. Ramasamy et al.,(Ramasamy et al., 2017) used S. portulacastrum to remediate soil contaminated by dye and textile effluent. In their study, the EC of the soil reduced from 13.04 to 7.37 $\mathrm{dSm}^{-1} 30$ days after planting. The EC further reduced to $5.34 \mathrm{dSm}^{-1} 60$ days after planting, with increased plant and biomass growth. After 90 days, $77.8 \%$ of the sodium content of the soil was removed. Similarly, Rabhi et al., (Rabhi et al., 2010) observed that phytodesalination with Sesuvium led to a 37\% decrease in the ECe of the upper horizon.

\section{Growth}

Under salt stress, S. portulacastrum exhibits various adaptations, including morphological, physiological, and biochemical modifications (Lokhande and Suprasanna, 2012). A significant increase in the shoot length, root length, and biomass was observed in plants grown with the treated effluent (Table 4).

A similar salt-induced growth was reported by Missedi et al., (2004) at a concentration of 100-400 mMNaCl. In their study, the plant growth stabilized at $800 \mathrm{mM}$. In the pot culture experiment, fresh biomass was produced at the rate of 8 ton per hectare in the soil irrigated with the treated effluent. In total, $24.2 \mathrm{~L}$ of effluent was used for irrigation during the 90-day period. The increased growth of $S$. portulacastrum on effluent addition may be due to the increased succulence, large nutrient supply, and optimum sodium content, which favour the growth of halophytes.

\section{Membrane damage}

Halophytes with a succulent morphology accumulate a higher volume of sodium in the vacuoles than in the cytoplasm (Hagibagheri and Clipson, 1986). However, due to the high salt stress, oxidative stress is developed, leading to the production of reactive oxygen species (ROS), which damage the lipids, proteins, and nucleic acid in plant cells (Skopelitis et al., 2006). The ELR was determined to ascertain the rate of membrane damage due to oxidative stress. On the continuous addition of treated effluent loaded with salts might had highest oxidative damage with $92 \%$ ELR compared with good-quality water irrigation@90 DAP compared to @ 30 DAP. An increased electrolyte leakage indicated increased electrolyte leaching from the cell to the external solution. The MDA content was also considerably higher in the effluent-irrigated treatments $\left(T_{1}\right)$ than in the samples irrigated with good-quality water. In $\mathrm{T}_{1}$, the MDA content increased at 90 DAP. Moreover, the MDA content at 60 DAP was marginally lower than that at $30 \mathrm{DAP}$. In $\mathrm{T}_{2}$, agradual increase in the MDA content was observed; however, the increase was not at a significant level.

\section{Osmolyte accumulation}

Osmotic stress due to salinity leads to a reduced water level and disruption in protein stability. 
Table.1 Initial characteristics of the soil used in the experiment

\begin{tabular}{|l|c|}
\hline \multicolumn{1}{|c|}{ Parameters } & Initial \\
\hline ECe $\left(\mathrm{dSm}^{-1}\right)$ & 4.57 \\
\hline $\mathrm{pH}$ & 8.17 \\
\hline ESP & 33.9 \\
\hline Organic Carbon $(\%)$ & 0.56 \\
\hline Available Nitrogen $\left(\mathrm{kgha}^{-1}\right)$ & 156 \\
\hline Available Phosphorus $\left(\mathrm{kgha}^{-1}\right)$ & 26.5 \\
\hline Available Potassium $\left(\mathrm{kgha}^{-1}\right)$ & 330 \\
\hline Exchangeable Calcium $\left.\left(\mathrm{cmol}^{+} \mathrm{p}^{+}\right) \mathrm{kg}^{-1}\right)$ & 6.80 \\
\hline Exchangeable Magnesium $\left(\mathrm{cmol}^{+}\left(\mathrm{p}^{+}\right) \mathrm{kg}^{-1}\right)$ & 2.60 \\
\hline Exchangeable Sodium $\left(\mathrm{cmol}\left(\mathrm{p}^{+}\right) \mathrm{kg}^{-1}\right)$ & 5.04 \\
\hline Exchangeable Potassium $\left(\mathrm{cmol}\left(\mathrm{p}^{+}\right) \mathrm{kg}^{-1}\right)$ & 0.42 \\
\hline Exchangeable Chloride $\left(\mathrm{cmol}\left(\mathrm{p}^{+}\right) \mathrm{kg}^{-1}\right)$ & 0.24 \\
\hline Exchangeable Bicarbonate $\left(\mathrm{cmol}\left(\mathrm{p}^{+}\right) \mathrm{kg}^{-1}\right)$ & 0.54 \\
\hline Soil Type & Saline- \\
& Sodic \\
\hline
\end{tabular}

Table.2 Characteristics of the treated effluent water used for irrigation

\begin{tabular}{|l|c|c|}
\hline \multicolumn{1}{|c|}{ Parameters } & Values & $\begin{array}{c}\text { CPCB Standards of } \\
\text { Irrigation Water, 1995 }\end{array}$ \\
\hline Total Dissolved Solids $\left(\mathrm{mgL}^{-1}\right)$ & 1860 & 2100 \\
\hline Total Suspended Solids $\left(\mathrm{mgL}^{-1}\right)$ & 100 & 200 \\
\hline $\mathrm{pH}$ & 8.01 & $5.5-9$ \\
\hline Electrical Conductivity $\left(\mathrm{dSm}^{-1}\right)$ & 3.57 & - \\
\hline $\begin{array}{l}\text { Biochemical Oxygen } \\
\text { Demand }\left(\mathrm{mgL}^{-1}\right)\end{array}$ & 31.4 & 100 \\
\hline Chemical Oxygen Demand $\left(\mathrm{mgL}^{-1}\right)$ & 251 & - \\
\hline Organic Carbon $(\%)$ & 0.56 & - \\
\hline Total Nitrogen $\left(\mathrm{mgL}^{-1}\right)$ & 252 & - \\
\hline Total Phosphorus $\left(\mathrm{mLL}^{-1}\right)$ & 213 & - \\
\hline Total Potassium $\left(\mathrm{mLL}^{-1}\right)$ & 390 & - \\
\hline Calcium $\left(\mathrm{mgL}^{-1}\right)$ & 228 & - \\
\hline Magnesium $\left(\mathrm{mgL}^{-1}\right)$ & 28.8 & - \\
\hline Sodium $\left(\mathrm{mLL}^{-1}\right)$ & 541 & - \\
\hline Chloride $\left(\mathrm{mgL}^{-1}\right)$ & 602 & - \\
\hline Sulphate $\left(\mathrm{mgL}^{-1}\right)$ & 90.6 & - \\
\hline Carbonate $\left(\mathrm{mgL}^{-1}\right)$ & 36.0 & - \\
\hline Bicarbonate $\left(\mathrm{mgL}^{-1}\right)$ & 292 & \\
\hline
\end{tabular}


Table.3 Changes in the physicochemical parameters on effluent water addition and remediation by $S$. portulacastrum ( $90^{\text {th }}$ day)

\begin{tabular}{|l|c|c|}
\hline \multicolumn{1}{|c|}{ Parameters } & Without Halophyte & $\begin{array}{c}\text { With Halophyte } \\
\text { (90 DAP) }\end{array}$ \\
\hline ECe $\left(\mathrm{dSm}^{-1}\right)$ & 6.97 & 3.01 \\
\hline $\mathrm{pH}$ & 7.25 & 7.21 \\
\hline ESP & 35.53 & 27.73 \\
\hline Organic Carbon $(\%)$ & 0.57 & 0.56 \\
\hline Available Nitrogen $\left(\mathrm{kgha}^{-1}\right)$ & 165 & 161.2 \\
\hline Available Phosphorus $\left(\mathrm{kgha}^{-1}\right)$ & 19.8 & 21.6 \\
\hline Available Potassium $\left(\mathrm{kgha}^{-1}\right)$ & 481 & 358.8 \\
\hline Exchangeable Calcium $\left(\mathrm{cmol}^{+}\left(\mathrm{p}^{+}\right) \mathrm{kg}^{-1}\right)$ & 8.89 & 8.40 \\
\hline Exchangeable Magnesium $\left(\mathrm{cmol}^{+} \mathrm{p}^{+} \mathrm{kg}^{-1}\right)$ & 3.18 & 2.50 \\
\hline Exchangeable Sodium $\left(\mathrm{cmol}\left(\mathrm{p}^{+}\right) \mathrm{kg}^{-1}\right)$ & 6.93 & 4.36 \\
\hline Exchangeable Potassium $\left(\mathrm{cmol}\left(\mathrm{p}^{+}\right) \mathrm{kg}^{-1}\right)$ & 0.61 & 0.46 \\
\hline Exchangeable Chloride $\left(\mathrm{cmol}\left(\mathrm{p}^{+}\right) \mathrm{kg}^{-1}\right)$ & 0.32 & 0.19 \\
\hline Exchangeable Bicarbonate $\left.\left(\mathrm{cmol}^{+} \mathrm{p}^{+}\right) \mathrm{kg}^{-1}\right)$ & 0.57 & 0.53 \\
\hline
\end{tabular}

Table.4 Effect of treated effluent and good-quality irrigation water on the shoot length, root length, and biomass at 30,60, and 90 DAP

\begin{tabular}{|c|c|c|c|c|c|c|c|c|c|c|c|c|}
\hline & \multicolumn{4}{|c|}{ Shoot Length (cm) } & \multicolumn{4}{|c|}{ Root Length (cm) } & \multicolumn{4}{|c|}{ Fresh Biomass $\left(\right.$ gpot $\left.^{-1}\right)$} \\
\hline & Initial & 30 DAP & 60 DAP & 90 DAP & Initial & 30 DAP & 60 DAP & 90 DAP & Initial & 30 DAP & 60 DAP & 90 DAP \\
\hline $\begin{array}{c}\text { Treated } \\
\text { Effluent }\left(\mathrm{T}_{1}\right)\end{array}$ & $5.3 \pm 0.89$ & $21.6 \pm 1.49$ & $30.6 \pm 2.25$ & $58.8 \pm 3.25$ & - & $12.1 \pm 3.25$ & $18.5 \pm 2.85$ & $22.9 \pm 2.44$ & $28 \pm 1.02$ & $164 \pm 2.34$ & $222.6 \pm 2.45$ & $320 \pm 2.35$ \\
\hline $\begin{array}{c}\text { Good- } \\
\text { Quality } \\
\text { Water }\left(\mathbf{T}_{2}\right)\end{array}$ & $5.3 \pm 0.89$ & $18.5 \pm 2.18$ & $26.8 \pm 3.12$ & $55.6 \pm 3.03$ & - & $8.1 \pm 4.10$ & $12.3 \pm 3.65$ & $18.6 \pm 3.45$ & $28 \pm 1.02$ & $160.3 \pm 1.77$ & $7220.3 \pm 1.64$ & $311.5 \pm 2.05$ \\
\hline
\end{tabular}

*Values represent the means of 10 replicatesand the SE at $5 \%$.

Table.5 Effect of treated paper mill effluent and good-quality water on the physiological and biochemical parameters of Sesuvium

\begin{tabular}{|c|c|c|c|c|c|c|}
\hline \multirow[t]{2}{*}{ Parameters } & \multicolumn{3}{|c|}{ Effluent-Treated $\left(\mathrm{T}_{1}\right)$} & \multicolumn{3}{|c|}{ Good-Quality Water $\left(T_{2}\right)$} \\
\hline & 30 DAP & 60 DAP & 90 DAP & 30 DAP & 60 DAP & 90 DAP \\
\hline Leaf Proline $\left(\mu \mathrm{g}^{-1} \mathrm{FW}\right)$ & $643 \pm 2.5$ & $655 \pm 1.84$ & $677 \pm 2.12$ & $222 \pm 1.42$ & $233 \pm 2.06$ & $246 \pm 2.45$ \\
\hline $\begin{array}{c}\text { Membrane Permeability } \\
\text { (ELR) }\end{array}$ & $69.2 \pm 0.72$ & $89.3 \pm 0.98$ & $91.8 \pm 1.05$ & $46.2 \pm 1.35$ & $57.0 \pm 0.75$ & $61.8 \pm 2.33$ \\
\hline Total Sugars (mg g ${ }^{-1}$ FW) & $22.2 \pm 0.38$ & $25.1 \pm 1.45$ & $17.4 \pm 1.9$ & $26.9 \pm 1.17$ & $17.3 \pm 1.33$ & $11.5 \pm 3.02$ \\
\hline MDA Content $\left(\mu \mathrm{mol} \mathrm{g}^{-1} \mathrm{FW}\right)$ & $1.11 \pm 0.60$ & $0.79 \pm 2.01$ & $3.67 \pm 1.11$ & $0.65 \pm 0.84$ & $0.78 \pm 0.99$ & $0.94 \pm 1.35$ \\
\hline Chlorophyll a ( $\left.\mathrm{mg} \mathrm{g}^{-1}\right)$ & $1.01 \pm 0.65$ & $0.79 \pm 1.65$ & $0.33 \pm 1.32$ & $0.85 \pm 1.20$ & $0.53 \pm 0.98$ & $0.30 \pm 1.61$ \\
\hline Chlorophyll b (mg g ${ }^{-1}$ ) & $0.98 \pm 0.54$ & $0.52 \pm 1.24$ & $0.18 \pm 0.92$ & $0.76 \pm 1.32$ & $0.49 \pm 1.20$ & $0.14 \pm 1.11$ \\
\hline Total Chlorophyll (mg g $\left.{ }^{-1}\right)$ & $1.99 \pm 1.09$ & $1.31 \pm 2.89$ & $0.50 \pm 2.24$ & $1.62 \pm 0.98$ & $1.02 \pm 2.18$ & $0.44 \pm 2.72$ \\
\hline
\end{tabular}

*Values represent the means of 10 replicatesand theSE at $5 \%$. 
Fig.1 Experiment with and without $S$. portulacastrum

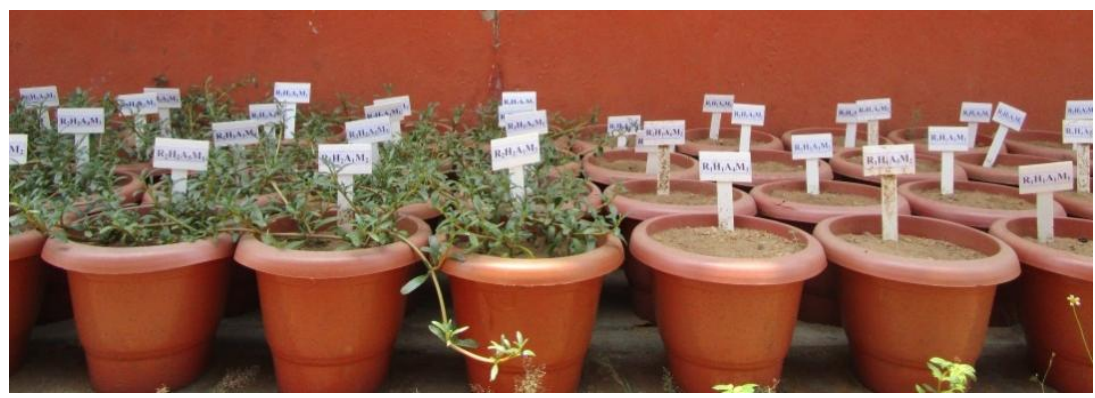

Fig.2 Ion composition of S. portulacastrum treated with (a) effluent and (b) good-quality water after 30days. The values represent the means of three replicates and the SE at 5\%
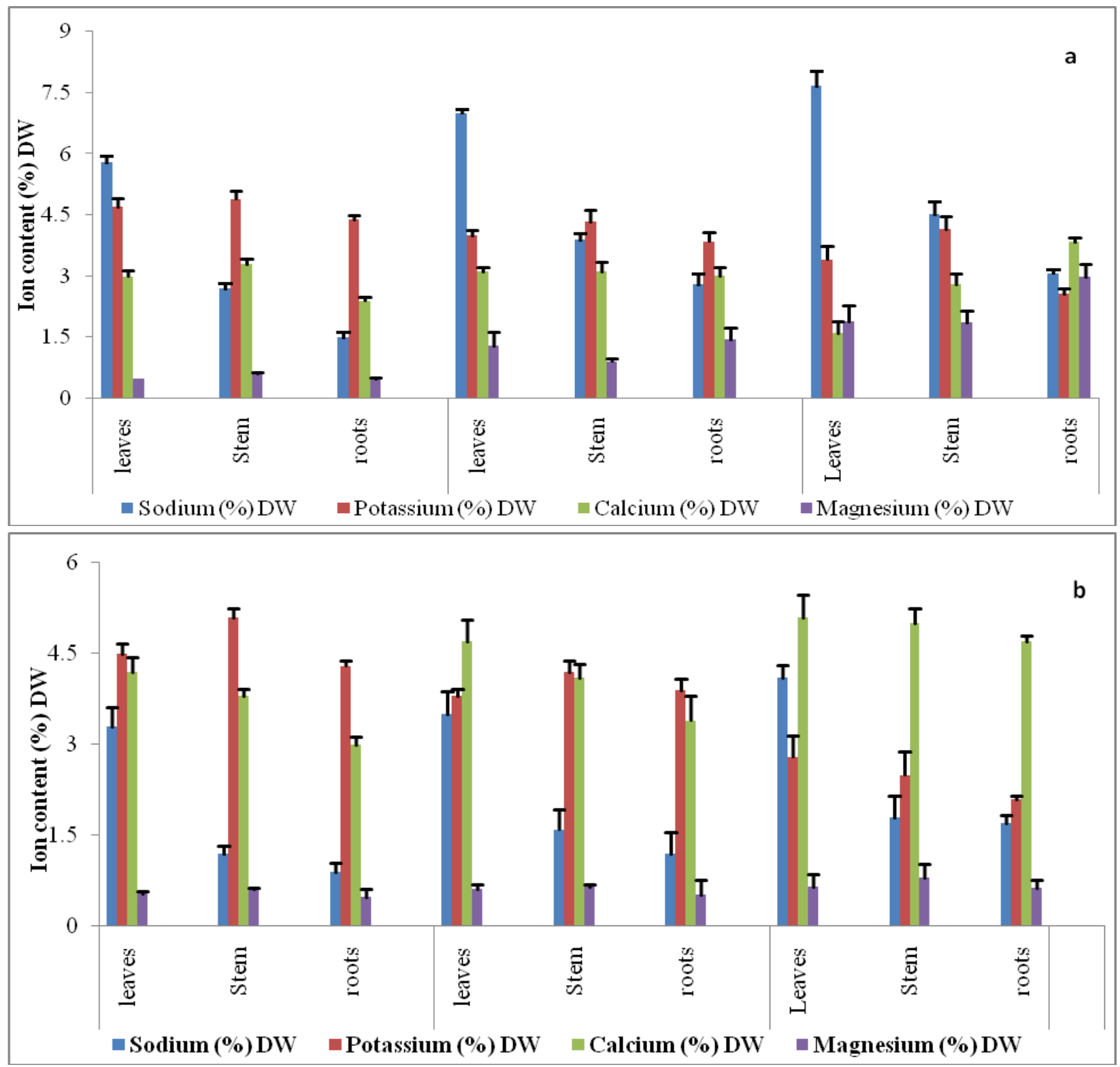
Fig.3 Schematic representing the experimental study and salt tolerance mechanism of S. portulacastrum. S. portulacastrum exhibits various mechanisms of salt tolerance, including physiological, biochemical, and anatomical adaptations. Salt addition leads to increased accumulation of $\mathrm{Na}^{+}$in the leaves. On the addition of treated pulp and paper mill effluent rich in saline and sodic ions (a), $S$. portulacastrum plant roots absorb an increased amount of sodium, chloride, and other ions (b). After sodium is accumulated in the leaves (c), the plants enhance tissue tolerance by $\mathrm{Na}^{+}$compartmentalisation in the vacuoles upto a certain limit (d). Excess saline stress leads to the production of ROS (e), which are balanced by the production of enzymatic antioxidants, such as catalase and SOD, and nonenzymatic osmoprotectants, such as proline, amino acids, and total sugars, which protect the membranes and enzymes. The plants also decrease the salinity by producing succulency in a chloride-rich environment (f). Overall, S. portulacastrum helps in the phytoremediation of salt-affected soils by removing saline salts (b)

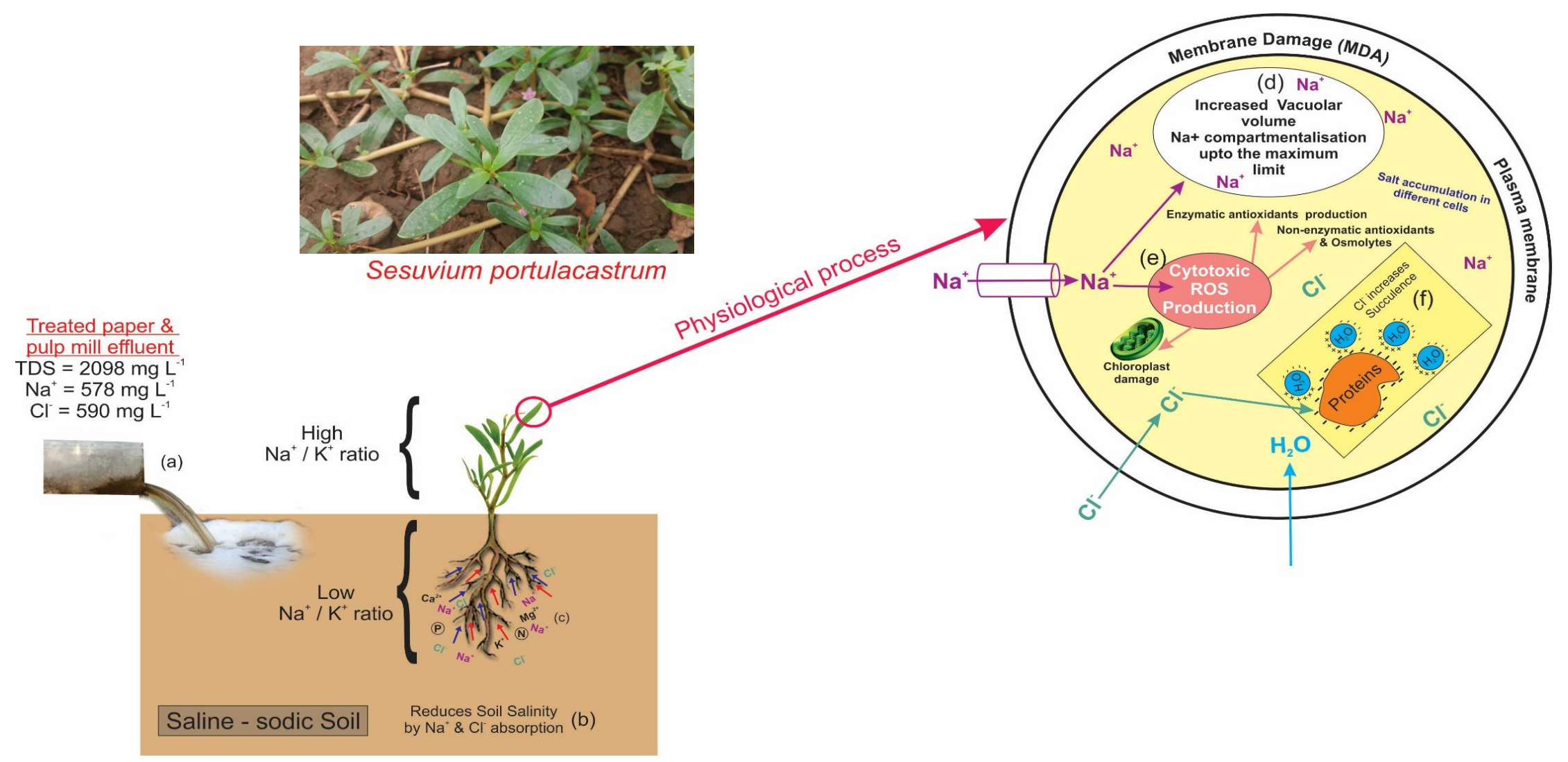


Osmotic adjustment through the accumulation of ions and production of organic osmolytes is the main adaptive mechanism of salt stress (Zhang et al., 1989).

Proline protects the structure of protein from denaturation, stabilizes the cell membrane by interacting with lipid molecules, and acts as an antioxidant (Lokhande et al., 2013). The proline content was lower in the plants treated with good-quality water than in the plants treated with effluent. In the samples treated with effluent, higher proline accumulation was observed at 90 DAP than at 30 and 60 DAP. When a plant is under abiotic stress, proline accumulates and nullifies the effect of stress factors through the detoxification of ROS and protection of proteins and their structures (Slama et al., 2015). A high level of proline upto $300 \mu^{-1} \lg ^{-1}$ leaf dry matter can be accumulated in response to stress by $S$. portulacastrum (Slama et al., 2006), which indicates thekey role of proline in osmotic regulation (Lokhande et al., 2010);(Moseki and Buru, 2010) for maintaining the cytoplasmic water potential (Hagibagheri and Clipson, 1986). A large amount of total sugars accumulated in S. portulacastrum at 30 and 60 DAP in the samples irrigated with treated paper mill effluent. The amount of total sugars decreased at 90 DAP. In the control samples, the total sugars decreased gradually after 30days. Upto 60 DAP, the total sugars may contribute to osmotic adjustment under salt stress. The osmotic adjustment decreases thereafter, which leads to increased cell damage. Studies have reported the use of sugars for complete osmotic adjustment despite the accumulation of proline (Pagter $e t$ al., 2009; Lokhande et al., 2010).

\section{Influence of salinity on the chlorophyll} content

Higher contents of chlorophyll a, chlorophyll $\mathrm{b}$, and total chlorophyll were observed in the
$\mathrm{T}_{1}$ samples than in the $\mathrm{T}_{2}$ samples. However, the chlorophyll content decreased at 90 DAP in both the control and treated samples, which may be due to the increased salinity on the continuous addition of salt water or due to ageing. The process of photosynthesisis affected under salt stress. The chlorophyll pigment system is damaged, and the stomatal conductance is reduced (Shabala et al., 2005). Ramani et al., (Ramani et al., 2006) reported that the chlorophyll a content increased at $400 \mathrm{~m} \mathrm{MNaCl}$ in S. portulacastrum.

In this study, the chlorophyll content was higher in the samples irrigated with the treated effluent (salinity stress) than in the samples treated with good-quality water (control), which indicated that the chlorophyll pigment system was unaffected under salinity stress in S. portulacastrum (Table 5).

\section{Ion composition}

The high sodium content in the shoots of $S$. portulacastrum is used for osmosis adjustments(Sleimi and Abdelly, 2002); (Messedi et al., 2004). The sodium concentration in the leaves was 2.5-3 times higher than that in the roots and stems. $S$. portulacastrum removed $183.5 \mathrm{~kg} \mathrm{Na}^{+} \mathrm{ha}^{-1}$ in 90 days, which can also be stated as the phytodesalination capacity of the halophyte. Sundararajet al.,(Sundararaj et al., 2014) noted that $S$. portulacastrum irrigated with primary effluent from the Pepsico industry could remove $1296 \mathrm{kgchlorideha}^{-1}$ and $114 \mathrm{~kg}$ sodium ha ${ }^{-1}$ within 90 days. Ravindran et al., (2007) reported that Sesuvium species could remove $474 \mathrm{~kg}$ sodium chloride $\mathrm{ha}^{-1}$ in 4 months.

The sodium content of the plants increased with time. The maximum concentration was noted at 90 DAP, which indicates that with increasing salinity, the sodium content increased and potassium content decreased. 
Similar results were observed by Slama et al., (2008) with increased $\mathrm{Na} / \mathrm{K}$ under salinity stress. Although the calcium and magnesium contents are lower under salinity stress, a considerable amount is accumulated (Venkatesalu et al., 1994), which indicates that the high concentration of $\mathrm{NaCl}$ does not affect the uptake of calcium (Messedi et al., 2004). In $S$. portulacastrum, calcium accumulates in the stem and leaves as calcium oxalate crystals, which are called druces (Fig.2). The magnesium content was higher in the stem than in the leaves. Similar results were obtained by Joshi and Bhosale (Joshi and Bhosale, 1982), who stated that magnesium ions are restrained in the stem itself and only a partial amount is transported to the leaves. The ion composition in good-quality water irrigated was contributed by the initial soil, which had high salt content.

The results of the experiment in this study indicate that $S$. portulacastrum can be used for the phytodesalination of saline and salinesodic soils even when the salinity continuously increases. Moreover, it can also be used in nonleaching conditions where the leaching of salinity with good-quality water is unfeasible. Thus, S. portulacastrum, which has high sodium and chloride absorption, may be a possible candidate for reducing secondary salinisation due to irrigation with sodium-rich industrial wastewater. During increased salt stress, $S$. portulacastrum adopted the following mechanism of salt tolerance(i) sodium was first accumulated in the vacuoles upto certain levels and then in the cytoplasm and protoplasm, (ii) high salt stress led to membrane damage due to high salt and ROS accumulation in the cells, (iii) osmolytes (proline and sugars) were produced for osmotic balance, (iv) $\mathrm{Na}$ ions beyond the vacuolar storage capacity were extruded, and (v) a larger amount of chloride anions accumulated as sodium and potassium salts with high sodium content compared to the later. Hence, $S$. portulacastrum is highly useful for the sustainable utilisation of industrial wastewater for irrigation, which is important for addressing the challenges caused by the emerging water scarcity problem worldwide.

\section{References}

Abrol, I., Yadav, J. S. P., and Massoud, F. (1988). Salt-affected soils and their management: Food and Agriculture Org.

Bates, L., Waldren, R., and Teare, I. (1973). Rapid determination of free proline for water-stress studies. Plant and soil, 39(1), 205-207.

Coll, J. B., Rodrigo, G. N., García, B. S., and Tamés, R. S. (1998). Fisiología vegetal: Pirámide.

Hagibagheri, M., and Clipson, N. (1986). Halophytes. Quart. Rev. Biol, 61, 313337.

Hasanuzzaman, M., Nahar, K., Alam, M. M., Bhowmik, P. C., Hossain, M. A., Rahman, M. M., Prasad, M. N., Ozturk, M., and Fujita, M. (2014). Potential use of halophytes to remediate saline soils. Biomed Res Int, 2014, 589341. doi: $10.1155 / 2014 / 589341$

Havlin, J. L., Beaton, J. D., Tisdale, S. L., and Nelson, W. L. (2005). Soil fertility and fertilizers: An introduction to nutrient management (Vol. 515): Pearson Prentice Hall Upper Saddle River, NJ.

Heath, R. L., and Packer, L. (1968). Photoperoxidation in isolated chloroplasts. Archives of Biochemistry and Biophysics, 125(3), 850-857.

Jackson, M. (1973). Methods of chemical analysis: Prentice Hall of India (Pvt.) Ltd., New Delhi.

Joshi, G., and Bhosale, L. J. (1982). Estuarine ecosystem of India Contributions to the Ecology of Halophytes (pp. 21-33): Springer.

Kömives, T., and Gullner, G. (2000). Phytoremediation. Plant-environment 
interaction. Marcel Dekker, New York, 437-452.

Laboratory, N. R. M. R. (2000). Introduction to phytoremediation: National Risk Management Research Laboratory, Office of Research and Development, US Environmental Protection Agency.

Lichtenthaler, H. K. (1987). [34] Chlorophylls and carotenoids: pigments of photosynthetic biomembranes Methods in enzymology (Vol. 148, pp. 350-382): Elsevier.

Lokhande, V. H., Gor, B. K., Desai, N. S., Nikam, T. D., and Suprasanna, P. (2013). Sesuvium portulacastrum, a plant for drought, salt stress, sand fixation, food and phytoremediation. A review. Agronomy for sustainable development, 33(2), 329-348.

Lokhande, V. H., Nikam, T. D., and Penna, S. (2010). Biochemical, physiological and growth changes in response to salinity in callus cultures of Sesuvium portulacastrum L. Plant Cell, Tissue and Organ Culture (PCTOC), 102(1), 17-25.

Lokhande, V. H., and Suprasanna, P. (2012). Prospects of halophytes in understanding and managing abiotic stress tolerance Environmental adaptations and stress tolerance of plants in the era of climate change (pp. 29-56): Springer.

Lutts, S., Kinet, J., and Bouharmont, J. (1995). Changes in plant response to $\mathrm{NaCl}$ during development of rice (Oryza sativa L.) varieties differing in salinity resistance. Journal of Experimental Botany, 46(12), 1843-1852.

Majumdar, K., Sanyal, S. K., Singh, V., Dutta, S., Satyanarayana, T., and Dwivedi, B. (2017). Potassium fertiliser management in Indian agriculture: current trends and future needs. Indian Journal of Fertilisers, 13(5), 20-30.
Messedi, D., Labidi, N., Grignon, C., and Abdelly, C. (2004). Limits imposed by salt to the growth of the halophyte Sesuvium portulacastrum. Journal of Plant Nutrition and Soil Science, 167(6), 720-725.

Moseki, B., and Buru, J. (2010). Ionic and water relations of Sesuvium portulacastrum (L.). Scientific Research and Essays, 5(1), 035-040.

Obi, A. (1974). The wilting point and available moisture in tropical forest soils of Nigeria. Experimental Agriculture, 10(4), 305-312.

Olsen, B., Cole, C., Watanab, P., and Dean, D. (1954). Estimation of available phosphorus in soils by extraction with sodium bicarbonate, U.S.D.A. Circ., p. 939.

Pagter, M., Bragato, C., Malagoli, M., and Brix, H. (2009). Osmotic and ionic effects of $\mathrm{NaCl}$ and $\mathrm{Na}_{2} \mathrm{SO}_{4}$ salinity on Phragmites australis. Aquatic Botany, 90(1), 43-51.

Rabhi, M., Giuntini, D., Castagna, A., Remorini, D., Baldan, B., Smaoui, A., Abdelly, C., and Ranieri, A. (2010). Sesuvium portulacastrum maintains adequate gas exchange, pigment composition, and thylakoid proteins under moderate and high salinity. Journal of plant physiology, 167(16), 1336-1341.

Ramani, B., Reeck, T., Debez, A., Stelzer, R., Huchzermeyer, B., Schmidt, A., and Papenbrock, J. (2006). Aster tripolium L. and Sesuvium portulacastrum L.: two halophytes, two strategies to survive in saline habitats. Plant Physiology and Biochemistry, 44(5-6), 395-408.

Ramasamy, J., Periasamy, K., and Venugopal, B. (2017). Phytoremediation Potential of Sesuvium Portulacastrum on Remediating. Current World Environment, 13(2). 
Ramesh Kannan, P., Deepa, S., Kanth, S. V., Rao, J. R., Gnanasekaran, C., and Rengasamy, R. (2009). Studies on the Use of Sesuvium Portulacastrum-Part III: Phytoremediation of Salt Contaminated Soils of Tannery Wastewater Discharged Lands. Journal of the American Leather Chemists Association.

Ravindran, K., Venkatesan, K., Balakrishnan, V., Chellappan, K., and Balasubramanian, T. (2007). Restoration of saline land by halophytes for Indian soils. Soil Biology and Biochemistry, 39(10), 2661-2664.

Science, I. S. O. S. (1929). Minutes of the first commission meetings, International Congress of Soil Science. Paper presented at the Proceedings of the Congress of the International Society of Soil Science.

Shabala, S., Shabala, L., Van Volkenburgh, E., and Newman, I. (2005). Effect of divalent cations on ion fluxes and leaf photochemistry in salinized barley leaves. Journal of Experimental Botany, 56(415), 1369-1378.

Sharma, V., Garg, U. K., and Arora, D. (2014). Impact of pulp and paper mill effluent on physico-chemical properties of soil. Arch Appl Sci Res, 6(2), 12-17.

Skopelitis, D. S., Paranychianakis, N. V., Paschalidis, K. A., Pliakonis, E. D., Delis, I. D., Yakoumakis, D. I., Kouvarakis, A., Papadakis, A. K., Stephanou, E. G., and RoubelakisAngelakis, K. A. (2006). Abiotic stress generates ROS that signal expression of anionic glutamate dehydrogenases to form glutamate for proline synthesis in tobacco and grapevine. The Plant Cell, 18(10), 2767-2781.

Slama, I., Abdelly, C., Bouchereau, A., Flowers, T., and Savoure, A. (2015).
Diversity, distribution and roles of osmoprotective compounds accumulated in halophytes under abiotic stress. Annals of Botany, 115(3), 433-447.

Slama, I., Ghnaya, T., Savouré, A., and Abdelly, C. (2008). Combined effects of long-term salinity and soil drying on growth, water relations, nutrient status and proline accumulation of Sesuvium portulacastrum. Comptes rendus biologies, 331(6), 442-451.

Slama, I., Messedi, D., Ghnaya, T., Savoure, A., and Abdelly, C. (2006). Effects of water deficit on growth and proline metabolism in Sesuvium portulacastrum. Environmental and experimental Botany, 56(3), 231-238.

Sleimi, N., and Abdelly, C. (2002). Growth and mineral nutrition of some halophytes under seawater irrigation Prospects for saline agriculture (pp. 403-410): Springer.

Stanford, G., and English, L. (1949). Use of the flame photometer in rapid soil tests for $\mathrm{K}$ and $\mathrm{Ca}$. Agronomy Journal, 41(9), 446-447.

Subbiah, B., and Asija, G. (1956). A rapid method for the estimation of nitrogen in soil. Current Science, 26, 259-260.

Sundararaj, R., Nagaraj, S., and Rengasamy, R. (2014). Assessment of $\mathrm{NaCl}$ accumulation and tolerance potential of Sesuvium portulacastrum L. J Acad Ind Res, 2(10), 578.

Tripathi, B. M., Kumari, P., Weber, K. P., Saxena, A. K., Arora, D. K., and Kaushik, R. (2014). Influence of long term irrigation with pulp and paper mill effluent on the bacterial community structure and catabolic function in soil. Indian journal of microbiology, 54(1), 65-73.

Venkatesalu, V., Kumar, R. R., and Chellappan, K. (1994). Growth and mineral distribution of Sesuvium 
portulacastrum L., a salt marsh halophyte, under sodium chloride stress. Communications in soil science and plant analysis, 25(15-16), 27972805.

Walkley, A., and Black, I. A. (1934). An examination of the Degtjareff method for determining soil organic matter, and a proposed modification of the chromic acid titration method. Soil science, 37(1), 29-38.

Watanabe, S., Kojima, K., Ide, Y., and Sasaki, S. (2000). Effects of saline and osmotic stress on proline and sugar accumulation in Populus euphratica in vitro. Plant Cell, Tissue and Organ Culture, 63(3), 199.

Zafrilla, B., Martinez-Espinosa, R. M., Alonso, M. A., and Bonete, M. J. (2010). Biodiversity of Archaea and floral of two inland saltern ecosystems in the Alto Vinalopo Valley, Spain. Saline Systems, 6, 10 . doi: 10.1186/1746-1448-6-10

Zhang, X., Zhang, G., Zhao, A., and Yu, T. (1989). Surface electrochemical properties of the B horizon of a Rhodic Ferralsol, China. Geoderma, 44(4), 275-286.

\section{How to cite this article:}

Iniyalakshimi, B. R., S. Avudainayagam, R. Shanmugasundaram, S. Paul Sebastian and Thangavel, P. 2019. Evaluation of Sesuvium portulacastrum for the Phytodesalination of Soils Irrigated over a Long-Term Period with Paper Mill Effluent under Nonleaching Conditions. Int.J.Curr.Microbiol.App.Sci. 8(12): 880-893. doi: https://doi.org/10.20546/ijcmas.2019.812.113 